\title{
The highly immunogenic enolase and Hsp70p are adventitious Candida albicans cell wall proteins
}

\author{
Pilar Eroles, Maria Sentandreu, M. Victoria Elorza \\ and Rafael Sentandreu
}

Author for correspondence: Rafael Sentandreu. Tel: +346 3864299. Fax: +3463864682.

e-mail: rafael.sentandreu@uv.es

Secció Departamental de Microbiologra, Facultat de Farmàcia, Universitat de València, Avgda. V. Andrés Estelles $s / n, 46100$

Burjassot, València, Spain

\begin{abstract}
Screening cDNA libraries with polyclonal antibody preparations against Candida albicans yeast or mycelial cell walls resulted in isolation of several positive clones. Some of them encoded enolase; others encoded a protein of the $70 \mathrm{kDa}$ heat-shock protein family (Hsp70p), etc. The presence of these cytosolic proteins in the cell wall of actively growing C. albicans was discovered by analytical (SDS-PAGE and Western blot) and cytological (indirect immunofluorescence) experiments. Supplementation of cell cultures with papulacandin B, an antibiotic that inhibits formation of the $\beta$-glucan skeleton, resulted in the release of enolase to the supernatant fluids; this release was prevented when $0.6 \mathrm{M} \mathrm{KCl}$ was present as an osmotic stabilizer. The cell wall of C. albicans incorporated exogenously added proteins (enolase and Escherichia coli and C. albicans cytosolic proteins). The presence in the $C$. albicans cell wall of enolase, Hsp70p, and probably other intracellular proteins that are highly immunogenic might help the fungal cells to evade the host defences, and consequently could represent a survival mechanism for C. albicans 'in vivo'.
\end{abstract}

Keywords: enolase, Hsp70p, cell wall, Candida albicans, antibodies

\section{INTRODUCTION}

Candida albicans is an opportunistic dimorphic pathogen that is emerging as a leading cause of deep-rooted infections mainly in immunocompromised patients. It is widely distributed in healthy individuals and initiation of infection is determined by the host conditions, its development depending on breakdown of the equilibrium between resistance and disease. Interaction between cell wall components and the immune system plays a fundamental role in controlling the infection and this is why the cell wall is considered to contain virulence factors (Elorza et al., 1985, 1988; Nelson et al., 1991; Calderone \& Fukayama, 1992; Gomez et al., 1993; Hazen \& Glee, 1994).

The C. albicans cell wall is composed mainly of $\beta$ glucans and mannoproteins, chitin being a minor component (Shepherd et al., 1985; Sentandreu et al., 1994). Some wall proteins are loosely associated with the cell walls and are released therefrom by chaotropic agents (SDS, urea, etc.). The remaining mannoproteins are solubilized after digestion with $\beta$-glucanases and chitinases, implying that they are covalently bonded to the $\beta$-glucan-chitin skeleton of the wall (Elorza et al., 1985, 1988; Kapteyn et al., 1995). Some wall mannoproteins are in addition linked to $1,6-\beta$-glucose residues (Kapteyn et al., 1994; Sanjuan et al., 1995).

The role of the proteins ranges from a structural function to a receptor-like function that mediates interactions between the fungus and tissues. Among these proteins, receptors for complement factors (Calderone et al., 1988; Gustafson et al., 1991; Alaei et al., 1993), as well as for fibrinogen (Bouali et al., 1987; Martínez et al., 1994), fibronectin (Kalon et al., 1988; Klotz \& Smith, 1991; Klotz et al., 1994), laminin (Bouchara et al., 1990; López-Ribot et al., 1994) and other extracellular matrix components (Klotz \& Maca, 1988; Klotz, 1990; LópezRibot \& Chaffin, 1994), are included.

During our efforts to isolate genes encoding cell wall proteins, we have cloned different known cytosolic proteins such as enolase (Sentandreu et al., 1995) and Hsp70p (Eroles et al., 1995). Both proteins have been reported to be circulating antigens in blood and to elicit an immune response during infection (Franklyn et al., 1990; Walsh et al., 1991). To confirm the finding of the 
genes encoding these proteins, the presence of these proteins on the cell surface was investigated and it was concluded that these and probably other cytosolic proteins can be bound to cell walls in vitro, as can happen in vivo. Their presence in the C. albicans cell wall seems to be a consequence of cell lysis and not a result of a secretory process.

\section{METHODS}

Strains and growth conditions. The strain of C. albicans used in this study was ATCC 26555 . Yeast cell cultures were maintained by subculturing every 2-3 weeks on slopes of Sabouraud Dextrose Agar and propagated in minimal medium supplemented with amino acids (Lee et al., 1975). Induction of germ tubes (mycelial cells) was carried out after cell starvation in sterile distilled water as previously described by Casanova et al. (1989). Cells were collected from the culture medium by spinning at $3000 \mathrm{~g}$ for $10 \mathrm{~min}$ at room temperature.

Escherichia coli $\mathrm{Y} 1090$ was used in the preparation of phageadsorbed polyclonal antibodies and to obtain cytosolic proteins. A loopful of $E$. coli was inoculated in $5 \mathrm{ml} \mathrm{LB}$ medium $\left(10 \mathrm{~g}\right.$ bactopeptone, $5 \mathrm{~g}$ yeast extract and $\left.10 \mathrm{~g} \mathrm{NaCl} \mathrm{l}^{-1}\right)$ supplemented with $0.2 \%(\mathrm{w} / \mathrm{v})$ maltose and $10 \mathrm{mM}$ magnesium sulphate, and grown overnight (see below).

Western blot techniques. Different subcellular fractions (cytosol, or SDS-, urea- or mercaptoethanol-solubilized cell wall material) and culture media from yeast cells and mycelial cells were obtained as follows. Cell walls were isolated by centrifugation and washing following cell breakage with glass beads as described by Elorza et al. (1988); non-covalently bound proteins were extracted with hot SDS or urea. In the first case, the cell walls were extracted with $2 \%(w / v)$ SDS in a boiling water-bath and the extracted material was recovered by spinning the suspension at $5000 \mathrm{~g}$ for $15 \mathrm{~min}$. Urea treatment was carried out by suspending the isolated cell walls $\left(20 \mathrm{mg}\right.$ ) in $12 \mathrm{M}$ urea and incubating at $30^{\circ} \mathrm{C}$ overnight. After spinning at $5000 \mathrm{~g}$ for $10 \mathrm{~min}$, the supernatant was dialysed against $8,6,4$ and $2 \mathrm{M}$ urea and distilled water for $42 \mathrm{~h}$ each at $4{ }^{\circ} \mathrm{C}$. Treatment with $\beta$-mercaptoethanol was carried out by suspending isolated cell walls in $100 \mathrm{ml} 1 \mathrm{M}$ ammonium acetate $(\mathrm{pH} \mathrm{6.3)} / 200 \mathrm{ml} \beta$-mercaptoethanol $/ 9.5 \mathrm{ml}$ distilled water and incubating at $30^{\circ} \mathrm{C}$ overnight. The solubilized material was obtained by centrifugation at $5000 \mathrm{~g}$ for $10 \mathrm{~min}$. Cytosolic fractions were prepared after separation of the cell walls by spinning the supernatant at $40000 \mathrm{~g}$ for $60 \mathrm{~min}$. The pellet corresponded to the membrane preparation, whereas the supernatant corresponded to the cytosolic preparation. The proteins were fractionated basically according to Laemmli (1970) on SDS-10\% polyacrylamide gels at a constant current of $25 \mathrm{~mA}$. The prestained molecular mass standards phosphorylase $B(106 \mathrm{kDa})$, bovine serum albumin $(80 \mathrm{kDa})$, ovalbumin $(49.5 \mathrm{kDa})$, carbonic anhydrase $(35.5 \mathrm{kDa})$, soyabean trypsin inhibitor $(27.5 \mathrm{kDa})$ and lysozyme $(18.5 \mathrm{kDa})$ (Bio-Rad) were run in parallel. After blotting to a nitrocellulose membrane (Bio-Rad Transblot cell), the proteins were detected by the ECL system (Western Blotting Protocols; Amersham) essentially as described in the Bio-Rad Immunoblot (GAR-HRP) assay kit based on the procedure of Burnette (1981) and Towbin et al. (1979) using polyclonal antibodies adsorbed against phage $11 \mathrm{~L}$ (enolase) or $2 \mathrm{M}(\mathrm{Hsp} 70 \mathrm{p})$ at a final concentration of $1: 500$ in $10 \mathrm{mM}$ Tris/ $/ \mathrm{HCl}(\mathrm{pH} 7 \cdot 4) / 3 \%$ $(\mathrm{w} / \mathrm{v})$ bovine serum albumin as a blocking agent $/ 0.9 \%$ $\mathrm{NaCl} / 0.05 \%$ Tween 20 (TBST). The blots were subsequently washed three times with TBST and incubated with a 1:12000 dilution of the peroxidase-labelled goat anti-rabbit antibody (Bio-Rad). Antiserum binding was visualized by use of the ECL fluorescent labelling kit and the chemiluminescent exposure of X-ray film.

Preparation of polyclonal antibodies adsorbed against phage 11L (enolase) or 2M (Hsp70p). Specific antibody preparations against enolase and Hsp70p were affinity-purified from those of polyclonal antibodies by adsorbing against the corresponding positive recombinant plaques of clones $2 \mathrm{M}$ and $11 \mathrm{~L}$. E. coli was grown overnight in $5 \mathrm{ml} \mathrm{LB}$, and $100 \mu \mathrm{l}$ of this suspension was infected with different amounts of the corresponding phage in $20 \mathrm{mM}$ Tris/ $\mathrm{HCl}(\mathrm{pH} 7 \cdot 4) / 100 \mathrm{mM}$ $\mathrm{NaCl} / 10 \mathrm{mM}$ magnesium sulphate and kept at $37^{\circ} \mathrm{C}$ for $30 \mathrm{~min}$. These suspensions were then mixed with $12 \mathrm{ml}$ melted LB medium plus $1 \%\left(\mathrm{w} / \mathrm{v}\right.$ ) agar, kept at $42^{\circ} \mathrm{C}$ for $30 \mathrm{~min}$, and were then spread on Petri dishes $(25 \mathrm{~cm})$ with LB plus $2 \%$ agar and incubated for $3 \mathrm{~h}$ at $42^{\circ} \mathrm{C}$ for the induction of the lytic phage cycle. The specific phage proteins were blotted onto nitrocellulose (Hybond-C) membranes (Amersham) by covering the plate with this membrane saturated in $10 \mathrm{mM}$ IPTG to induce the expression of the $\beta$-galactosidase fusion protein. The blotted membrane was then used to immunoadsorb the polyclonal antibody preparations $(5 \mathrm{ml}$ of the original polyclonal preparation) for $30 \mathrm{~min}$ and after several washes in $20 \mathrm{ml}$ TBST; the adsorbed antibodies were eluted from the membrane with $4 \mathrm{ml} 100 \mathrm{mM}$ glycine $(\mathrm{pH} 2 \cdot 8)$. The eluted material was neutralized with drops of a $3 \mathrm{M}$ Tris $/ \mathrm{HCl}(\mathrm{pH}$ 8.5) solution.

Incorporation of purified enolase by $\mathrm{C}$. albicans cell walls. Yeast cell walls $(20 \mathrm{mg}$ wet $\mathrm{wt}$ ) were extracted with $1 \mathrm{ml}$ of boiling $2 \%$ SDS solution in glass-distilled water for $10 \mathrm{~min}$ at $100^{\circ} \mathrm{C}$, and following three washes with distilled water $(3000 \mathrm{~g}, 10 \mathrm{~min})$ were incubated with $10 \mathrm{mg}$ Saccharomyces cerevisiae enolase (Sigma) in a final volume of $1 \mathrm{ml}$ distilled water. After $30 \mathrm{~min}$ at 37 or $0{ }^{\circ} \mathrm{C}$, the cell walls were washed again three times as described above, extracted with hot $2 \%$ SDS, analysed by SDS-PAGE and after blotting stained with specific adsorbed antibodies.

Treatment of $C$. albicans cells with antibiotics. Starved C. albicans cells ( $1 \mathrm{mg}$ wet wt ml $\left.\mathrm{m}^{-1}\right)$ were resuspended in Lee medium (Lee et al., 1975) and after $2 \mathrm{~h}$ at 28 or $37^{\circ} \mathrm{C}$ supplemented with papulacandin $\mathrm{B}\left(2 \mathrm{mg} \mathrm{ml}^{-1}\right)$ or papulacandin $B\left(2 \mathrm{mg} \mathrm{ml}^{-1}\right)$ in $0.6 \mathrm{M} \mathrm{KCl}$ and incubated again at either 28 or $37^{\circ} \mathrm{C}$. The spent media were collected by centrifugation at $3000 \mathrm{~g}$ for $10 \mathrm{~min}$, dialysed against distilled water (three times) and after freeze-drying were analysed by SDS-PAGE and Western blotting with monospecific polyclonal antibodies.

Indirect immunofluorescence labelling. Cells or cell walls were washed three times with PBS ( $10 \mathrm{mM}$ sodium phosphate, $150 \mathrm{mM}$ sodium chloride, $\mathrm{pH} 7.4$ ) and incubated at $37^{\circ} \mathrm{C}$ for $1 \mathrm{~h}$ with the appropriate dilution in PBS of the specific phageadsorbed polyclonal antibodies. After three washes with PBS, the cells were incubated with fluorescein-isothiocyanateconjugated anti-rabbit IgG (Boehringer Mannheim) diluted $1: 10$ in PBS at $37^{\circ} \mathrm{C}$ for $1 \mathrm{~h}$. After three washes with PBS, a few drops of the suspension were placed on slides and examined with an ACAS 470 laser confocal microscope (Meridian Instruments), equipped with a $5 \mathrm{~W}$ argon-ion laser, operating at an excitation wavelength of $488 \mathrm{~nm}$ and with an emission filter of $510 \mathrm{~nm}$, using a $\times 100$ oil immersion objective lens. The confocal optical section thickness was $0.5 \mathrm{~mm}$, corresponding to the upper surface of the cells, and 
the final power of the laser was $0 \cdot 1 \mathrm{~mW}$. All immunofluorescence localization experiments were performed at least three times and the micrographs depicted representative results. Image acquisition and fluorescence intensity measurements were coordinated by computer software (Meridian Instruments).

Incorporation of $\boldsymbol{E}$. coli and $\boldsymbol{C}$. albicans cytosolic proteins in the C. albicans cell wall. E. coli was grown in $50 \mathrm{ml} \mathrm{LB}$ medium supplemented with radiolabelled protein hydrolysate $\left[0.2 \mu \mathrm{Ci}\left(7.4 \times 10^{3} \mathrm{~Bq}\right) \mathrm{ml}^{-1}\right.$; Moravek Biochemicals] and incubated by shaking at $37^{\circ} \mathrm{C}$ for $60 \mathrm{~min}$. The cells were then harvested by centrifugation at $10000 \mathrm{~g}$ for $20 \mathrm{~min}$, washed three times with PBS and the suspension of $E$. coli in PBS $(5 \mathrm{ml})$ was sonicated for $30 \mathrm{~s}$ (four times). During the intervals ( $2 \mathrm{~min}$ ) the suspension was kept in an ice-bath. The suspension was spun down at $40000 \mathrm{~g}$ for $30 \mathrm{~min}$ and the cytosolic fraction was collected.

C. albicans cells $\left(0.5 \mathrm{mg}\right.$ dry $\left.\mathrm{wt} \mathrm{m}^{-1}\right)$ were suspended in Lee medium $(40 \mathrm{ml})$ containing radiolabelled protein hydrolysate $\left[0.2 \mu \mathrm{Ci}(7.4 \mathrm{kBq}) \mathrm{ml}^{-1}\right.$; Moravek Biochemicals], incubated at $28^{\circ} \mathrm{C}$ for $3 \mathrm{~h}$ and following breakage in a Braun homogenizer (Melsungen) (Casanova et al., 1989) the cytosol was prepared by spinning at $40000 \mathrm{~g}$ for $5 \mathrm{~min}$.

The pellet of non-radioactive C. albicans cell walls (equivalent to $40 \mathrm{mg}$ wet wt) was supplemented with the E. coli or C. albicans cytosolic fractions. After $30 \mathrm{~min}$ at $28^{\circ} \mathrm{C}$, the walls were collected by centrifugation at $4000 \mathrm{~g}$ for $10 \mathrm{~min}$, washed three times with PBS and the radioactivity was measured before and after extraction with hot $2 \%$ SDS solutions.

\section{RESULTS}

We have previously described the isolation of different cDNA clones by immunoscreening expression libraries with polyclonal antibodies raised against cell wall components (Sentandreu et al., 1995). From 29 positives, 12 clones (11L and others) encoded the enzyme enolase (Sentandreu et al., 1995) and three clones (2M plus two more) encoded a protein belonging to the $70 \mathrm{kDa}$ heatshock proteins (Eroles et al., 1995). Other clones encoded novel proteins (results to be described elsewhere). These results were surprising as enolase and Hsp70p are located intracellularly (Sundstrom \& Aliaga, 1992; Pelham, 1986; Boorstein et al., 1994) and the lambda gt11 libraries had been screened with polyclonal antibody preparations against isolated cell walls.

\section{Location of the proteins encoded by clones $11 \mathrm{~L}$ and 2M}

To find out the actual location of the gene products encoded, phage-adsorbed polyclonal antibodies were used (see Methods). These antibody preparations were employed to probe the presence of the corresponding proteins in cytoplasmic extracts of both yeast and mycelial cells and in the material released from isolated walls treated with either SDS, urea or $\beta$-mercaptoethanol, and the material solubilized by Zymolyase after SDS extraction. For the $11 \mathrm{~L}$ clone (enolase), a protein band of $48 \mathrm{kDa}$ was detected. This band was found in the cytosol, and in the SDS, mercaptoethanol and urea

\section{(a)}

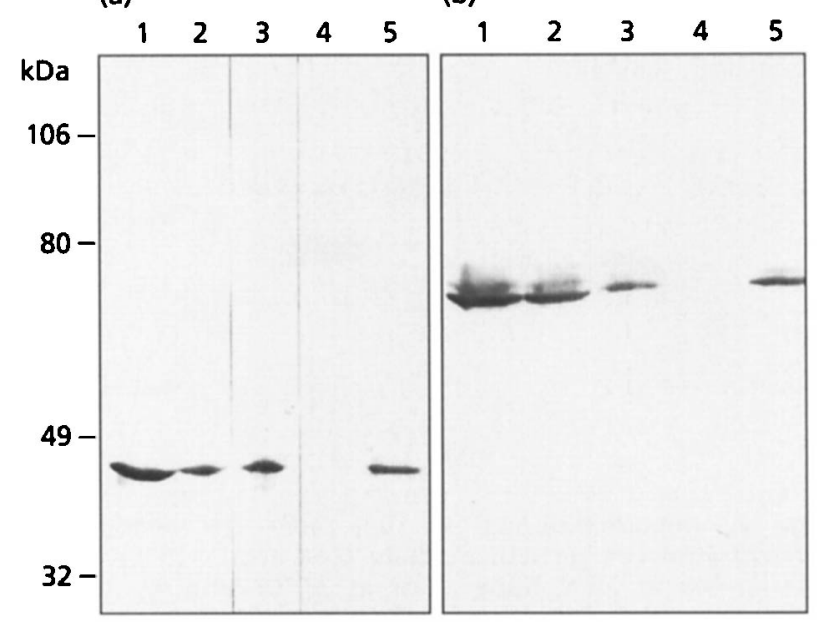

Fig. 1. Immunoblots of $10 \%$ slab gels loaded with the $2 \%$ SDS (lane 1), mercaptoethanol (lane 2) and urea (lane 3) extracts of the yeast cell walls, with the Zymolyase digest (lane 4) of the yeast cell walls and the cytosol (lane 5) stained with polyclonal antibodies adsorbed against phage $11 \mathrm{~L}$ (enolase) (a) or $2 \mathrm{M}$ (Hsp70p) (b) as described in Methods. Molecular masses of standard proteins are indicated on the left.

extracts of isolated cell walls (Fig. 1). The 11L antibody detected nothing in the material solubilized with Zymolyase. When the experiment was repeated and the blots were immunoreacted with the phage-adsorbed polyclonal antibody against $2 \mathrm{M}(\mathrm{Hsp} 70 \mathrm{p})$, a band of $70 \mathrm{kDa}$ was again detected in the cytosol and the SDS, urea and $\beta$-mercaptoethanol extracts. The electrophoretic mobility of both proteins located in the walls was the same as that of the proteins detected in the cytosol (Fig. 1). No protein was detected in the materials released by the Zymolyase (Fig. 1).

\section{Effect of the antibiotic papulacandin B}

To find out the effect of the inhibition of the $\beta$-glucans on the localization of the enolase and Hsp70p the following experiments were done. Yeast cells growing actively in Lee medium were supplemented with papulacandin $\mathrm{B}$, an inhibitor of $\beta$-glucan formation (Baguley et al., 1979; Font de Mora et al., 1993), and after $4 \mathrm{~h}$ incubation at $28^{\circ} \mathrm{C}$, the spent media were collected by centrifugation, dialysed and freeze-dried. The material collected was analysed by SDS-PAGE, blotted to nitrocellulose and probed with the anti-enolase phageadsorbed polyclonal antibodies. The antigen was detected only in the cultures where C. albicans had been grown in the presence of papulacandin B (Fig. 2). In contrast, the antigen could not be detected in the spent media of the control cells. Interestingly enough, when the cells were grown in papulacandin B but in a hypertonic medium $(0.6 \mathrm{M} \mathrm{KCl})$, the enolase could not be detected in the cell supernatant (Fig. 2). These results suggest that the origin of enolase in the walls could be due to its previous release from dead cells. 


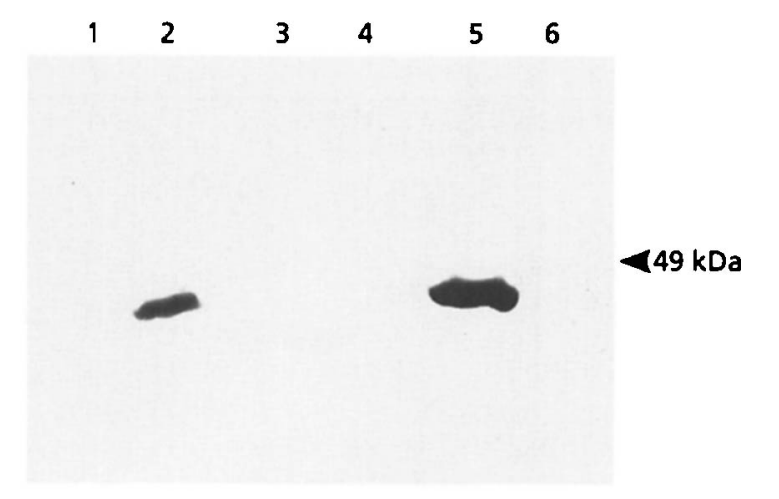

Fig. 2. Immunoblot of a $10 \%$ slab gel loaded with concentrated Lee growth medium (Lee et al., 1975) of yeast cells grown at $28^{\circ} \mathrm{C}$ (lane 1) or at $37^{\circ} \mathrm{C}$ (lane 4), following supplementation with papulacandin B at $28^{\circ} \mathrm{C}$ (lane 2) or at $37^{\circ} \mathrm{C}$ (lane 5), or with papulacandin B plus $0.6 \mathrm{M} \mathrm{KCl}$ at $28^{\circ} \mathrm{C}$ (lane 3) or at $37^{\circ} \mathrm{C}$ (lane 6). The molecular mass of enolase is indicated on the right.

\section{Location of enolase and Hsp70p on the cell surface}

The results reported above indicate that enolase and Hsp70p proteins are localized cytoplasmically but are also on the cell surface. To demonstrate that this was so, the presence of the two proteins on the surface of $C$. albicans was analysed with the help of a confocal laser microscope. Fig. 3 illustrates the fluorescent pseudocolour images of the surface of yeast cells and mycelial cells, both of which showed relatively low but significant amounts of enolase and Hsp70p (Fig. 3). This experiment was carried out with living cells and antibody did not get into the cytoplasm under the conditions used. Distribution of the antigens was irregular, resembling mosaics, giving a variegated appearance to the walls. In the mycelial cells, the receptors of the phage-adsorbed antibodies, i.e. the antigens, seemed more abundant in apical and subapical areas. When the isolated walls were treated with hot $2 \%$ SDS solutions, neither the enolase nor Hsp70p could be detected on the wall surface (Fig. $3)$.

\section{Incorporation of purified enolase into the isolated yeast wall}

An additional experiment was carried out to understand why the enolase was located in C. albicans cell walls. Yeast cell walls were extracted with hot $2 \%$ SDS solutions, and after removal of detergent by washing, were supplemented with a solution of $10 \mu \mathrm{g}$ commercial yeast enolase in $1.0 \mathrm{ml} 1.0 \mathrm{mM}$ PMSF in distilled water for $30 \mathrm{~min}$, either at 0 or $30^{\circ} \mathrm{C}$. The walls were then washed several times with $1.0 \mathrm{mM}$ PMSF to eliminate the residual enolase, extracted with hot $2 \%$ SDS solutions and blotted to nitrocellulose paper and probed with anti-11L antibodies. In the native walls, the antibodies detected a single band of $49 \mathrm{kDa}$ corresponding to enolase. A similar band was produced by the walls incubated in the presence of commercial yeast enolase independently of temperature (Fig. 4). C. albicans enolase migrates slightly faster than $S$. cerevisiae enolase (Sundstrom \& Aliaga, 1994).

\section{Incorporation of E. coli and C. albicans cytosolic proteins into the $C$. albicans cell wall}

The experiments previously described suggest that enolase and Hsp70p present on the surface of C. albicans could have a cytoplasmic origin due to their release by cell death or by other unknown means. To obtain additional information, the following experiment was carried out. E. coli and C. albicans cells were grown independently in ${ }^{14} \mathrm{C}$-labelled protein hydrolysate and the radioactive cytosolic preparations (Methods) were added to a suspension of purified C. albicans cell walls that had grown in a 'cold' non-radioactive medium. Significant radioactivity was retained in all cases. Practically all proteins retained by the walls were released by hot $2 \%$ SDS solutions (Table 1 ).

\section{DISCUSSION}

The ability of C. albicans to change from a yeast to a mycelial morphology and to switch between different colonial morphologies is thought to give additional advantages to this pathogenic fungus in its ability to colonize different tissues and to evade the host defence mechanisms simultaneously. These phenomena are probably dependent on many parameters, one of them being the composition of the cell wall (Nelson et al., 1991; Glee et al., 1995; Bromuro et al., 1994). The use of classical genetic approaches to understand the molecular mechanisms implicated in the regulation of the morphological changes in C. albicans is very difficult due to the lack of a sexual cycle. Consequently we tried to identify genes present in cDNA expression libraries of yeast cells and mycelia whose products are components of the cell wall. With this aim, we obtained polyclonal antibody preparations raised against yeast and mycelial cell walls. The screened cDNA libraries gave several positive clones, more than $50 \%$ of which, as detected with antibodies against yeast cell walls, encode enolase (a glycolytic enzyme). A heat-shock protein of $70 \mathrm{kDa}$ (Hsp70p) (another cytosolic protein) and another glycolytic enzyme, phosphoglycerate mutase, among other proteins, were detected with antibodies against mycelial walls. Similar results have also been obtained by various authors using different antibody preparations (Sundstrom \& Aliaga, 1992; La Valle et al., 1995).

Cloning of genes encoding enolase, Hsp70p and other proteins (results to be described elsewhere) was surprising because these proteins are located in the cytoplasm (Sundstrom \& Aliaga, 1992; Pelham, 1986). The presence of these proteins in the cell wall was ascertained by analytical (SDS-PAGE and Western blot) and cytological (indirect immunofluorescence) experiments. Although in the blotting experiments the origin of the proteins could be due to the inevitable immersion, at least briefly, of the isolated cell wall in the cytosol, the 
(a)

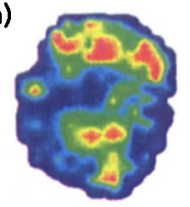

(c)

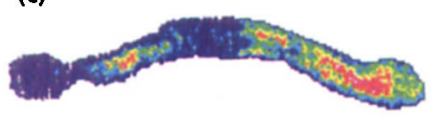

(e)

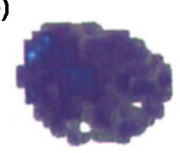

(b)

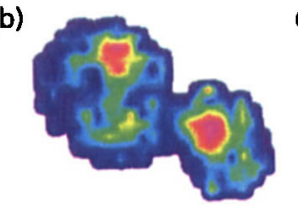

(d)

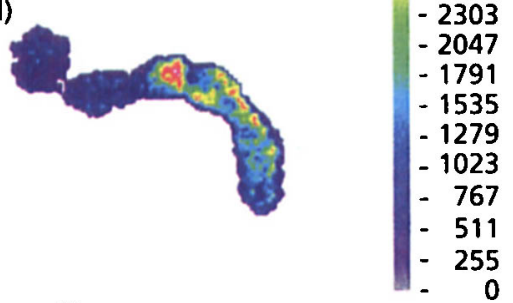

Colour values

$-4095$

$-3839$

$-3583$

$-3327$

3071

$-2815$

2559

2303

(535

279

767

255

(f)

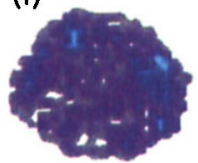

Fig. 3. Indirect immunofluorescence of yeast cells $(a, b)$, mycelial cells $(c, d)$ and yeast cell walls treated with $2 \% \operatorname{SDS}(e, f)$ stained with polyclonal antibodies adsorbed against phage 11L (enolase) (a, c, e) or 2M (Hsp70p) $(b, d, f)$. The observations were carried out with a confocal laser microscope (Methods) and the relative value of the fluorescence emitted is shown to the right.

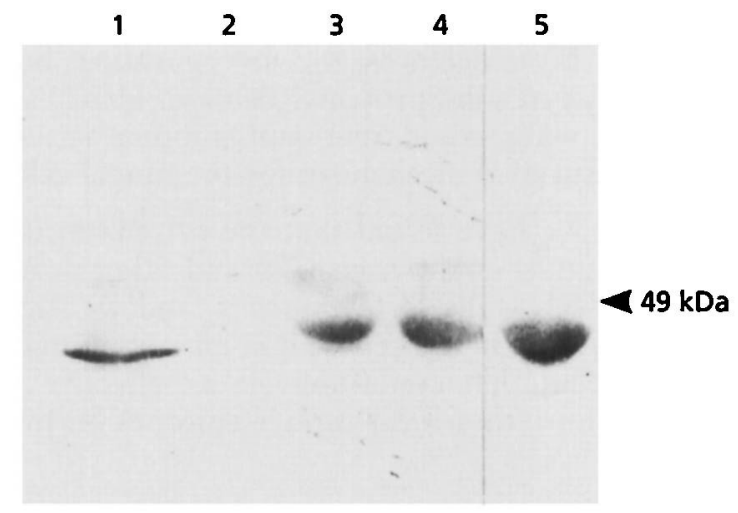

Fig. 4. Immunoblot of a $10 \%$ slab gel loaded with a $2 \%$ SDS extract of yeast cell walls (lane 1), with a second SDS extract (lane 2), with walls treated with $2 \%$ SDS after incubation with $10 \mathrm{mg}$ enolase at $37^{\circ} \mathrm{C}$ for $30 \mathrm{~min}$ (lane 3) or at $0^{\circ} \mathrm{C}$ for $30 \mathrm{~min}$ (lane 4 ) and $2 \mathrm{mg}$ enolase (lane 5) stained with polyclonal antibodies adsorbed against phage $11 \mathrm{~L}$ (enolase). The molecular mass of enolase is indicated on the right. microscopic experiments were carried out in vivo and the antibodies do not penetrate into the cytoplasm in the absence of cell permeabilization. Therefore it is possible that proteins that had been cloned were also present in the cell walls. Confirmation of this hypothesis was obtained by three complementary experiments: (i) supplementation of a cell culture with papulacandin B, an antibiotic that blocks formation of the $\beta$-glucan skeleton (Baguley et al., 1979; Font de Mora et al., 1993), resulted in the release of enolase to the supernatant fluids; (ii) this release could be avoided if the cells were grown in the presence of an osmotic stabilizer $(0.6 \mathrm{M} \mathrm{KCl})$; and (iii) C. albicans yeast cell walls could, in addition, incorporate exogenously added proteins (enolase and E. coli and C. albicans cytosolic proteins). These results suggest that enolase and $4 s p 70 p$, and probably other proteins in the C. albicans cell wall, have a cytoplasmic origin.

In agreement with this interpretation, Sundstrom \& Aliaga (1994) have demonstrated that enolase is found in

\section{Table 1. Incorporation of $C$. albicans and $E$. coli proteins by $C$. albicans isolated cell walls}

${ }^{14} \mathrm{C}$-labelled cytosolic proteins obtained from C. albicans and E. coli were added to a suspension of isolated non-radioactive SDSextracted C. albicans cell walls. The cell walls were, after $30 \mathrm{~min}$ at $28^{\circ} \mathrm{C}$, washed three times with $50 \mathrm{ml} 0.010 \mathrm{M}$ phosphate buffer $(\mathrm{pH} 7 \cdot 4)$ plus $0 \cdot 9 \% \mathrm{NaCl}$ and their radioactivity was measured before and after extraction with hot SDS solutions. The values are the mean of at least three separate experiments and the SD values were never higher than $10 \%$ of the mean.

\begin{tabular}{|lccccc|}
\hline \multirow{2}{*}{$\begin{array}{l}\text { Cytosolic } \\
\text { proteins }\end{array}$} & \multicolumn{5}{c|}{ Radioactivity } \\
\cline { 2 - 6 } & $\begin{array}{c}\text { Added } \\
\text { (c.p.m.) }\end{array}$ & $\begin{array}{c}\text { Retained } \\
\text { (c.p.m.) }\end{array}$ & $\begin{array}{c}\text { Percentage } \\
\text { retained }\end{array}$ & $\begin{array}{c}\text { SDS-extracted } \\
\text { (c.p.m.) }\end{array}$ & $\begin{array}{c}\text { Percentage } \\
\text { incorporated by } \\
\text { isolated walls }\end{array}$ \\
\hline C. albicans & 173346 & 162150 & 93.54 & 155580 & 95.94 \\
E. coli & 867056 & 158840 & $18 \cdot 32$ & 154005 & $97 \cdot 00$ \\
\hline
\end{tabular}


cell supernatants of C. albicans and suggested that this is due to either cell lysis or leakage. Even though they failed to detect enolase on the cell surface of formalinkilled hyphal cells, their interpretation of the extracellular presence of C. albicans is in agreement with our results. These authors also indicated that host defences may contribute to fungal death, and as a consequence, to the circulating enolase in haematogenously disseminated candidiasis. The high abundance of the enolase protein and its antigenic and physical properties lead to its selective detection in cell supernatants over other proteins that are also released following rupture or lysis during infection. Here, we present evidence of the cell surface location of enolase, not only by immunofluorescence of whole cells but also by Western blotting of different subcellular fractions.

Recently, Angiolella et al. (1996) reported that enolase could be covalently connected to the cell wall $1,3-\beta$ glucan, as it is released following Zymolyase (a $\beta$ glucanase complex) digestion. These authors did not extract cell walls with detergents prior to Zymolyase treatment (to remove non-covalently bound proteins), and this may be the reason why they detected enolase in the cell wall digest. Boiling SDS, as well as other ionic detergents and chaotropic agents, releases different proteins from isolated walls of $S$. cerevisiae and $C$. albicans that are loosely associated with the wall. These proteins are also solubilized by Zymolyase digestion in the absence of such treatments. Contrary to enolase, these proteins show typical features of intrinsic cell wall proteins as their sequences display both signal peptide and glycosylation sites that are characteristic of cell wall and secreted proteins.

Both enolase and Hsp70 proteins have been observed to be major antigens in several infectious diseases (Bianco et al., 1986). From our results, we cannot conclude that the presence of $\mathrm{Hsp} 70 \mathrm{p}$ in the cell wall is due to secretion, because its sequence, as in the case of enolase, lacks both signal peptide and glycosylation sites (Eroles et al., 1995; Angiolella et al., 1996).

The results described in this paper point to the $C$. albicans cell wall being a 'sticky' structure and that enolase, Hsp70p and other cytoplasmic proteins could be found in it as a result of cell lysis or any other unknown mechanism. Elimination of these proteins from isolated walls by SDS solutions indicates that they are present in the wall and retained by non-covalent bonds.

C. albicans has been in contact with humans for thousands of years and an equilibrium has been reached; the human host controls the growth of the fungal cells under normal living conditions. When this equilibrium breaks down as a result of a stress situation (iatrogenic treatments, e.g. antibiotics; immunodepressing processes, e.g. cancer, HIV; or immunosuppression interventions, e.g. organ transplantation), the ability of the immune system is reduced and reacts mainly with the most immunogenic antigens. It has been reported that
C. albicans infection induces in the host the production of antibodies against enolase (Franklyn et al., 1990; Postlethwait \& Sundstrom, 1995; Sundstrom \& Aliaga, 1994), a $90 \mathrm{kDa}$ heat-shock protein (Matthews \& Burnie, 1989), an antigen of $96 \mathrm{kDa}$ and a heat-shock protein of $75 \mathrm{kDa}$ (Constantino et al., 1994). These antigens and other intracellular proteins could partially cover the cell surface.

Morphological and colonial switching have been considered important characteristics of C. albicans in the processes that mediate colonization. Furthermore, other unknown mechanisms surely play important roles, helping penetration into the host tissues and organs. Several parasites express different epitopes during the process of colonization of the host. Plasmodium falciparum escapes the immune defences of the host by producing variations in the intragenic repetitive sequences in the genes that encode surface antigens such as MSA1 (Frontali, 1994) and MSA2 (Felger et al., 1994; Marshall et al., 1994; Anders et al., 1993; McColl et al., 1994) and in an Hsp70 homologue found throughout the asexual blood cycle and in gametocytes (Bianco et al., 1986). The results reported in this paper suggest that evading the host defences by incorporating highly immunogenic cytosolic proteins (enolase, Hsp70, etc.) into the cell walls could represent another virulence factor and a survival mechanism for the fungal cells.

In summary, we have found that the cytoplasm is the probable origin of enolase, Hsp70p and other proteins found in the cell walls of $C$. albicans, and we suggest that their presence in the cell wall in vivo may produce a 'smokescreen' that could subvert an effective host immune response to critical surface epitopes on fungal antigens.

\section{ACKNOWLEDGEMENTS}

This work was partially supported by grants from the Dirección General de Investigación Científica y Técnica (PB93-0051) del Ministerio de Educación y Ciencia and from the Fondo de Investigaciones Sanitarias de la Seguridad Social del Ministerio de Sanidad y Consumo (95/1602), Madrid, Spain. We thank Mrs Caridad Carrillo for the microscopic experiments. P.E. and M.S. were recipients of predoctoral grants from the Direcció General de Universitat e Investigació de la Generalitat Valenciana, València, Spain.

\section{NOTE ADDED IN PROOF}

A protein related to the Hsp70p family has been described to be present in the cell wall of C. albicans that is extracted with $\beta$-mercaptoethanol solutions (López-Ribot et al., 1996).

\section{REFERENCES}

Alaei, S., Larcher, C., Ebenbichler, C., Prodinger, W. M., Janatova, J. \& Dierich, M. P. (1993). Isolation and biochemical characterization of the $\mathrm{iC} 3 \mathrm{~b}$ receptor of Candida albicans. Infect Immun 61, 1395-1399.

Anders, R. F., McColl, D. J. \& Coppel, R. L. (1993). Molecular variation in Plasmodium falciparum: polymorphic antigens of asexual erythrocytic stages. Acta Trop 53, 239-253. 
Angiolella, L., Facchin, M., Stringaro, A., Maras, B., Simonetti, N. \& Cassone, A. (1996). Identification of a glucan-associated enolase as a main cell wall protein of Candida albicans and an indirect target of lipopeptide antimycotics. J Infect Dis 173, 684-690.

Baguley, B. C., Römmele, G. J. \& Wehrli, W. (1979). Papulacandin B: an inhibitor of glucan synthesis in yeast spheroplasts. Eur J Biochem 97, 345-351.

Bianco, A. E., Favaloro, J. M., Burkot, T. R., Culvenor, J. G., Crewther, P. E., Brown, G. V., Anders, R. F., Coppel, R. L. \& Kemp, D. J. (1986). A repetitive antigen of Plasmodium falciparum that is homologous to heat shock protein 70 of Drosophila melanogaster. Proc Natl Acad Sci USA 83, 8713-8717.

Boorstein, W. R., Ziegelhoffer, T. \& Craig, E. A. (1994). Molecular evolution of the Hsp70 multigene family. J Mol Evol 38, 1-17.

Bouali, A., Robert, R., Tronchin, G. \& Senet, J. M. (1987). Characterization of binding of human fibrinogen to the surface of germ-tubes and mycelium of Candida albicans. J Gen Microbiol 133, 545-551.

Bouchara, J. P., Tronchin, G., Annaix, V., Robert, R. \& Senet, J. M. (1990). Laminin receptors on Candida albicans germ tubes. Infect Immun 58, 48-54.

Bromuro, C., Torosantucci, A., Gomez, M. J., Urbani, F. \& Cassone, A. (1994). Differential release of an immunodominant $65 \mathrm{kDa}$ mannoprotein antigen from yeast and mycelial form of Candida albicans. J Med Vet Mycol 32, 447-459.

Burnette, W. N. (1981). 'Western blotting': electrophoretic transfer of proteins from sodium dodecyl sulphate-polyacrylamide gels to unmodified nitrocellulose and radiographic detection with antibody and radioiodinated protein A. Anal Biochem 112, 195-203.

Calderone, R. \& Fukayama, M. (1992). Virulence-associated mannoproteins of Candida albicans. In Emerging Targets in Antibacterial and Antifungal Chemotherapy, pp. 524-545. Edited by J.A. Sutcliffe \& N. H. Georgepapadakon. New York: Chapman and Hall.

Calderone, R. A., Linehan, L., Wadsworth, E. \& Sandberg, A. L. (1988). Identification of C3d receptors on Candida albicans. Infect Immun 56, 252-258.

Casanova, M., Gil, M. L., Cardeñoso, L., Martínez, J.P. \& Sentandreu, R. (1989). Identification of wall-specific antigens synthesized during germ tube formation by Candida albicans. Infect Immun 57, 262-271.

Constantino, P. J., Franklyn, K. M., Gare, N. F. \& Warmington, J. R. (1994). Production of antibodies to antigens of Candida albicans in CBA/H mice. Infect Immun 62, 1400-1405.

Elorza, M. V., Murgui, A. \& Sentandreu, R. (1985). Dimorphism in Candida albicans: contribution of mannoproteins to the architecture of yeast and mycelial cell walls. J Gen Microbiol 131, 2209-2216.

Elorza, M. V., Marcilla, A. \& Sentandreu, R. (1988). Wall mannoproteins of the yeast and mycelial cells of Candida albicans: nature of the glycosidic bonds and polydispersity of their mannan moieties. J Gen Microbiol 134, 2393-2403.

Eroles, P., Sentandreu, M., Elorza, M. V. \& Sentandreu, R. (1995). Cloning of a DNA fragment encoding part of a $70-\mathrm{kDa}$ heat shock protein of Candida albicans. FEMS Microbiol Lett 128, 95-100.

Felger, I., Tavui, L., Kabintik, S., Marshall, V., Genton, B., Alpers, M. \& Beck, H. P. (1994). Plasmodium falciparum: extensive polymorphism in merozoite surface antigen 2 alleles in an area with endemic malaria in Papua New Guinea. Exp Parasitol 79, 106-116.
Font de Mora, J., Herrero, E. \& Sentandreu, R. (1993). A kinetic study on the regeneration of Candida albicans protoplasts in the presence of cell wall synthesis inhibitors. FEMS Microbiol Lett 111, 43-48.

Franklyn, K. M., Warmington, J. R., Ott, A. K. \& Ashman, R. B. (1990). An immunodominant antigen of Candida albicans shows homology to the enzyme enolase. Immunol Cell Biol 68, 173-178.

Frontali, C. (1994). Genome plasticity in Plasmodium. Genetica 94, 91-100.

Glee, P., Sundstrom, M. \& Hazen, K. C. (1995). Expression of surface hydrophobic proteins by Candida albicans in vivo. Infect Immun 63, 1373-1379.

Gomez, M. J., Torosantucci, A., Quinti, I., Testa, U., Peschle, C. \& Cassone, A. (1993). Mannoprotein-induced anti-U937 cell cytotoxicity in peripheral blood mononuclear cells from uninfected or HIV-infected subjects: role of interferon-gamma and tumor necrosis factor a cells. Infect Immun 152, 530-543.

Gustafson, K. S., Vercelloti, G. M., Bendel, C. M. \& Hostetter, M. K. (1991). Molecular mimicry in Candida albicans. Role of an integrin analogue in adhesion of yeast to human endothelium. J Clin Invest 87, 1896-1902.

Hazen, K. C. \& Glee, P. M. (1994). Hydrophobic cell wall protein glycosylation by the pathogenic fungus Candida albicans. Can J Microbiol 40, 266-272.

Kalon, A., Segal, E., Shar, E. \& Dayan, D. (1988). Interaction of Candida albicans with genital humoral surfaces: involvement of fibronectin in adherence. J Infect Dis 57, 1253-1256.

Kapteyn, J. C., Montijn, R. C., Dijkgraaf, G. J.P. \& Klis, F. M. (1994). Identification of $\beta-1,6$-glucosylated cell wall proteins in yeast and hyphal forms of Candida albicans. Eur J Cell Biol 65, 402-407.

Kapteyn, J. C., Dijkgraaf, G. J. P., Montijn, R. C. \& Klis, F. M. (1995). Glycosylation of cell wall proteins in regeneration spheroplasts of Candida albicans. FEMS Microbiol Lett 128, 271-277.

Klotz, S. A. (1990). Adherence of Candida albicans to components of the subendothelial extracellular matrix. FEMS Microbiol Lett 68, 249-254.

Klotz, S. A. \& Maca, R. D. (1988). Endothelial cell contraction increases Candida adherence to exposed extracellular matrix. Infect Immun 56, 2495-2498.

Klotz, S. A. \& Smith, R. L. (1991). A fibronectin receptor on Candida albicans mediates adherence of the fungus to extracellular matrix. J Infect Dis 163, 604-610.

Klotz, S. A., Hein, R. C., Smith, R. L. \& Rouse, J. B. (1994). The fibronectin adhesin of Candida albicans. Infect Immun 62, 4679-4681.

Laemmli, U. K. (1970). Cleavage of structural proteins during the assembly of the head of bacteriophage T4. Nature 227, 680-685.

La Valle, R., Bromuro, C., Ranucci, L., Muller, H.-M., Crisanti, A. \& Cassone, A. (1995). Molecular cloning and expression of a 70 kilodalton heat shock protein of Candida albicans. Infect Immun 63, 4039-4045.

Lee, K. L., Buckley, M. R. \& Campbell, C. (1975). An amino acid liquid synthetic medium for development of mycelial and yeast forms of Candida albicans. Sabouraudia 13, 148-153.

López-Ribot, J. L. \& Chaffin, W. L. (1994). Binding of the extracellular matrix component entactin to Candida albicans. Infect Immun 62, 4564-4571.

López-Ribot, J. L., Casanova, M., Monteagudo, C., Sepulveda, P. 
\& Martínez, J. P. (1994). Evidence for the presence of a highaffinity laminin receptor-like molecule on the surface of Candida albicans yeast cells. Infect Immun 62, 742-746.

López-Ribot, J. L., Alloush, H. M., Masten, B. J. \& Chaffin, W. L. (1996). Evidence for presence in the cell wall of Candida albicans of a protein related to the hsp70 family. Infect Immun 64, 3333-3340.

McColl, D. J., Silva, A., Foley, M., Kun, J. F., Favaloro, J. M., Thompson, J. K., Marchall, V. M., Coppel, R. L., Kemp, D. J. \& Anders, R. F. (1994). Molecular variation in a novel polymorphic antigen associated with Plasmodium falciparum merozoites. $\mathrm{Mol}$ Biochem Parasitol 68, 53-67.

Marshall, V. M., Anthony, R. L., Bangs, M. J., Purnomo, Anders, R. F. \& Coppel, R. L. (1994). Allelic variants of the Plasmodium falciparum merozoite surface antigen 2 (MSA-2) in a geographically restricted area of Irian Jaya. Mol Biochem Parasitol 63, 13-21.

Martínez, J. P., López-Ribot, J. L. \& Chaffin, L. J. (1994). Heterogeneous surface distribution of the fibrinogen-binding protein on Candida albicans. Infect Immun 62, 709-712.

Matthews, R. \& Burnie, J. (1989). Cloning of a DNA sequence encoding a major fragment of the 47 kilodalton stress protein homologue of Candida albicans. FEMS Microbiol Lett 51, 25-30.

Nelson, R. D., Shibata, N., Podzorski, R. P. \& Herron, M. J. (1991). Candida mannan: chemistry, suppression of cell-mediated immunity, and possible mechanisms of action. Clin Microbiol Rev 4, 1-19.

Pelham, H. R. B. (1986). Speculations on the functions of the major heat shock and glucose-related proteins. Cell 46, 959-961.

Postlethwait, P. \& Sundstrom, P. (1995). Genetic organization and mRNA expression of enolase genes of Candida albicans. $J$ Bacteriol 177, 1772-1779.

Sanjuán, R., Zueco, J., Stock, R., Font de Mora, J. \& Sentandreu, R. (1995). Identification of glucan-mannoprotein complexes in the cell wall of Candida albicans using a monoclonal antibody that reacts with a $(1,6)$ - $\beta$-glucan epitope. Microbiology 141, 1545-1551.

Sentandreu, R., Mormeneo, S. \& Ruiz-Herrera, J. (1994). Biogenesis of the fungal cell wall. In The Mycota. 1. Growth, Differentiation and Sexuality, pp. 111-124. Edited by J. G. H. Wessels \& F. Meinhart. Berlin \& Heildelberg: Springer-Verlag.

Sentandreu, M., Elorza, M. V., Sentandreu, R. \& Gozalbo, D. (1995). Cloning of cDNAs coding for Candida albicans cell surface proteins. J Med Vet Mycol 33, 105-111.

Shepherd, M. G., Poulter, R. T. M. \& Sullivan, P. A. (1985). Candida albicans: biology, genetics and pathogenicity. Annu Rev Microbiol 39, 579-614.

Sundstrom, P. \& Aliaga, G. R. (1992). Molecular cloning of cDNA and analysis of protein secondary structure of Candida albicans enolase, an abundant, immunodominant glycolytic enzyme. $J$ Bacteriol 174, 6789-6799.

Sundstrom, P. \& Aliaga, G. R. (1994). A subset of proteins found in culture supernatants of Candida albicans includes the abundant, immunodominant, glycolytic enzyme enolase. J Infect Dis 169, 452-456.

Towbin, H., Staehelin, T. \& Gordon, J. (1979). Electrophoretic transfer of proteins from polyacrylamide gels to nitrocellulose sheets : procedure and some applications. Proc Natl Acad Sci USA 76, $4350-4354$.

Walsh, T. J., Hathorn, J. W., Sobel, J. D. \& 12 other authors (1991). Detection of circulating Candida enolase by immunoassay in patients with cancer and invasive candidiasis. N Engl J Med 324, 1026-1031.

Received 21 May 1996; revised 6 September 1996; accepted 14 October 1996. 